\title{
Phospholemman Does Not Participate in Forskolin-Induced Swine Carotid Artery Relaxation
}

\author{
M. K. MEEKS, S. HAN, A. L. TUCKER, C. M. REMBOLD \\ Cardiovascular Division, Department of Internal Medicine, University of Virginia Health System \\ Charlottesville, Virginia, USA
}

Received July 10, 2007

Accepted August 28, 2007

On-line October 11, 2007

\begin{abstract}
Summary
Phosphorylation of phospholemman (PLM) on $\operatorname{ser}^{68}$ has been proposed to at least partially mediate cyclic AMP (CAMP) mediated relaxation of arterial smooth muscle. We evaluated the time course of the phosphorylation of phospholemman (PLM) on $\operatorname{ser}^{68}$, myosin regulatory light chains (MRLC) on $\operatorname{ser}^{19}$, and heat shock protein 20 (HSP20) on $\operatorname{ser}^{16}$ during a transient forskolininduced relaxation of histamine-stimulated swine carotid artery. We also evaluated the dose response for forskolin- and nitroglycerin-induced relaxation in phenylephrine-stimulated $\mathrm{PLM}^{-/}$and $\mathrm{PLM}^{+/+}$mice. The time course for changes in $\operatorname{ser}^{19}$ MRLC dephosphorylation and $\operatorname{ser}^{16}$ HSP2O phosphorylation was appropriate to explain the forskolin-induced relaxation and the recontraction observed upon washout of forskolin. However, the time course for changes in ser ${ }^{68}$ PLM phosphorylation was too slow to explain forskolin-induced changes in force. There was no difference in the phenylephrine contractile dose response or in forskolin-induced relaxation dose response observed in $\mathrm{PLM}^{-/-}$and $\mathrm{PLM}^{+/+}$aortae. In aortae precontracted with phenylephrine, nitroglycerin induced a slightly, but significantly greater relaxation in $\mathrm{PLM}^{-/}$compared to $\mathrm{PLM}^{+/+}$aortae. These data are consistent with the hypothesis that $\operatorname{ser}^{19}$ MRLC dephosphorylation and ser $^{16}$ HSP2O phosphorylation are involved in forskolininduced relaxation. Our data suggest that PLM phosphorylation is not significantly involved in forskolin-induced arterial relaxation.
\end{abstract}

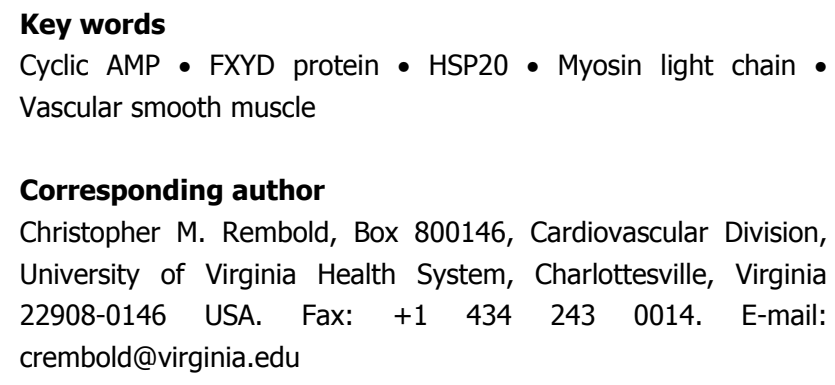

\section{Introduction}

Vascular smooth muscle contraction primarily involves pathways whereby increases in myoplasmic calcium $\left(\left[\mathrm{Ca}^{2+}\right]_{\mathrm{i}}\right)$ activate myosin light chain kinase, which phosphorylates myosin regulatory light chains (MRLC) on $\operatorname{ser}^{19}$ (Murphy and Rembold 2005). MRLC phosphorylation can also be increased by inhibition of MRLC phosphatase (Somlyo and Somlyo 2000, Etter et al. 2001)). Increases in $\operatorname{ser}^{19}$-MRLC phosphorylation cause contraction. We term these processes "activation."

Relaxation can occur by two general mechanisms: 1) "Deactivation" is the reversal of activation involving dephosphorylation of MRLC by either a reduction in $\left[\mathrm{Ca}^{2+}\right]_{i}$ or an increase in MRLC phosphatase activity (Rembold 1991, Gerthoffer and Murphy, 1983, Etter et al. 2001). 2) "Force suppression" is relaxation that occurs while MRLC phosphorylation levels remain elevated in the presence of excitatory stimuli (McDaniel et al. 1992, Bárány and Bárány 1993, Rembold et al. 2001). Phosphorylation of heat shock protein 20 (HSP20), also known as HspB6 (Fan et al. 2005)) on ser16 (Beall et al. 1997, Beall et al. 1999, Woodrum et al. 1999, Jerius et al. 1999) has been proposed to be the mediator of force suppression (Rembold et al. 2000, Rembold et al. 2001, Meeks et al. 2005). cAMP-mediated relaxation, e.g. by forskolin treatment, can induce relaxation by both deactivation (Rembold and Chen 1998) and force suppression (Rembold et al. 2001).

Phospholemman (PLM, also known as FXYD1) was also proposed to be involved in cAMP-mediated smooth muscle relaxation (Rembold et al. 2005). There 
are four papers describing the physiology of PLM in smooth muscle. The first three predate the naming of PLM but describe a plasma membrane phosphoprotein that copurified with $\mathrm{Na}, \mathrm{K}-\mathrm{ATPase}$ (Boulanger-Saunier et al. 1985), was phosphorylated on one site by agents that increase cAMP and PKA (Boulanger-Saunier et al. 1985, Sarcevic et al. 1989), was phosphorylated on a second site by contractile agonists and phorbol esters (Boulanger-Saunier and Stoclet 1987), and was not phosphorylated by protein kinase G (PKG) (Sarcevic et al. 1989). With phosphospecific PLM antibodies (Rembold et al. 2005), we found that: 1) histamine stimulation induced a swine carotid artery contraction associated with a small increase in $\operatorname{ser}^{68}$ PLM phosphorylation. 2) Forskolin-induced relaxation was associated with a further increase in $\operatorname{ser}^{68}$ PLM phosphorylation. 3) Nitroglycerin-induced relaxation was not associated with a further increase in $\operatorname{ser}^{68}$ PLM phosphorylation. 4) Pretreatment with $1 \mu \mathrm{M}$ forskolin for 15 min significantly reduced swine carotid contraction induced by zero extracellular $\mathrm{Na}^{+}$, suggesting that forskolin reduced $\left[\mathrm{Na}^{+}\right]_{\mathrm{i}}$. These findings suggested a potential role for ser $^{68}$ PLM phosphorylation in cAMPmediated relaxation of arterial smooth muscle.

The goal of this study was to determine the role of PLM in cAMP-mediated arterial smooth muscle relaxation. We tested whether the phosphorylation status of PLM, HSP20, and MRLC correlated with forskolininduced swine carotid artery relaxation and the recontraction observed with washout of forskolin. We also tested whether genetic absence of PLM in PLM $^{-/-}$ mice alters forskolin- and nitroglycerin-induced relaxation in aortae compared to the aortae of $\mathrm{PLM}^{+/+}$ mice. PLM $^{-/}$mice were previously found to develop modest cardiac hypertrophy without an alteration in blood pressure compared to $\mathrm{PLM}^{+/+}$mice (Jia et al. 2005).

\section{Methods}

\section{Swine carotid experiments}

Swine carotid artery rings, obtained from an abattoir, were mounted, stretched to their optimal length, pharmacologically treated, frozen, and analyzed for PLM phosphorylation, HSP20 phosphorylation, and MRLC phosphorylation as previously described (Rembold et al. 2001, Rembold et al. 2005).

\section{Mouse aorta preparation}

Dr. Amy Tucker engineered and provided $\mathrm{PLM}^{-/-}$ and $\mathrm{PLM}^{+/+}$mice (Jia et al. 2005). Under an University of Virginia approved IACUC protocol, mice were euthanized with $\mathrm{CO}_{2}$ followed by cervical dislocation. Segments of mouse infrarenal abdominal aortae (length $\sim 1.5 \mathrm{~mm}$ ) were dissected and mounted on a MulvanyHalpern dual wire myograph (Danish Myotechnology model 610M, Aarhus, Denmark). The physiological saline solution (PSS) contained (in $\mathrm{mM}$ ) $140 \mathrm{NaCl}, 4.7$ $\mathrm{KCl}, 1.2 \mathrm{Na}_{2} \mathrm{HPO}_{4}, 1.6 \mathrm{CaCl}_{2}, 1.2 \mathrm{MgCl}_{2}, 5.6$ D-glucose, 2.0 morpholinopropane sulfonic acid buffer $(\mathrm{pH} 7.4$ at 4 or $37^{\circ} \mathrm{C}$ ), and 0.02 ethylenediamine N,N'-tetraacetic acid (EDTA) to chelate trace heavy metal ions. Tissues were stretched to a resting force of $\sim 1$ gram-weight as described in the results. Changes in extracellular $\left[\mathrm{K}^{+}\right]_{\mathrm{o}}$ were made by stoichiometric replacement of $\mathrm{Na}^{+}$with $\mathrm{K}^{+}$. Since the tissues were small, individual tissue weights could not be accurately measured. Therefore, force was normalized to the steady state force induced by $109 \mathrm{mM}$ $\mathrm{K}^{+}$depolarization.

\section{[cAMP] measurement}

Two $\mathrm{mm}$ long segments of abdominal aortae were incubated freely floating as described in the results, then frozen in acetone/dry ice, thawed slowly, homogenized in $0.1 \mathrm{M} \mathrm{HCl}$, and analyzed for [cAMP] by radioimmunoassay as described (McDaniel et al. 1991).

\section{Statistics}

Differences were evaluated with Student's unpaired $t$ test and significance was defined as $\mathrm{p}<0.05$.

\section{Results}

We performed a time course of forskolininduced relaxation to test whether ser ${ }^{68}$ phosphorylation of phospholemman (PLM) was involved in forskolininduced relaxation. For a phosphorylation to be involved in the relaxation, the change in phosphorylation should precede or parallel the forskolin-induced relaxation and the reverse change in phosphorylation should precede or parallel the recontraction observed when forskolin is washed out (Rembold et al. 2001).

Activation of swine carotid artery rings with $10 \mu \mathrm{M}$ histamine for $30 \mathrm{~min}$ increased ser $^{68}$-PLM phosphorylation, ser ${ }^{19}$-MRLC phosphorylation, and contractile force without significantly altering $\operatorname{ser}^{16}$ HSP20 or ser $^{157}$-HSP20 phosphorylation (30 $\mathrm{min}$ in Fig. 1, the dashed lines represent the values of each measured after $30 \mathrm{~min}$ in histamine). Addition of $1 \mu \mathrm{M}$ 


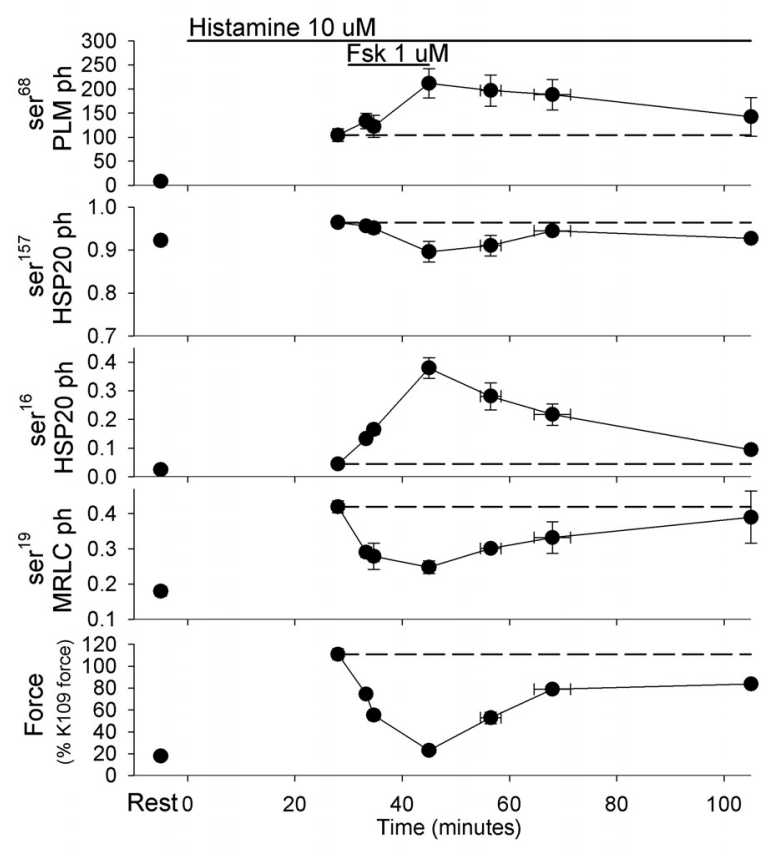

Fig. 1. The time course of ser ${ }^{68}$-PLM phosphorylation (top panel), ser ${ }^{157}$-HSP20 phosphorylation (second panel), ser ${ }^{16}$-HSP20 phosphorylation (third panel), ser ${ }^{19}$-MRLC phosphorylation (fourth panel), and force (bottom panel) in swine carotid contracted with histamine, relaxed with forskolin, and recontracted by washout of forskolin in the continued presence of histamine. Nine sets of swine carotid artery tissues were stimulated with $10 \mu \mathrm{M}$ histamine for a total of $105 \mathrm{~min}$ starting at $0 \mathrm{~min}$ in the figure. Forskolin $(1 \mu \mathrm{M})$ was added to the histamine for only $15 \mathrm{~min}$, from 30 to $45 \mathrm{~min}$ in the figure. Tissues from each set were frozen at various times (data points left to right): 1) prior to histamine stimulation (labeled rest), 2) after $30 \mathrm{~min}$ of $10 \mu \mathrm{M}$ histamine stimulation alone, 3) when forskolin induced a 25\% relaxation ( $3.3 \pm 0.5 \mathrm{~min}$ after forskolin addition), 4) when forskolin induced a $\sim 50 \%$ relaxation $(4.7 \pm 0.9 \mathrm{~min}$ after forskolin addition), 5) 15 min after addition of forskolin, 6) when washout of forskolin in the presence of histamine induced a recontraction to $\sim 50 \%$ of maximal force $(11.5 \pm 1.9 \mathrm{~min}$ after forskolin washout), 7) when washout of forskolin in the presence of histamine induced a recontraction to $\sim 75 \%$ of maximal force ( $23 \pm 3.4 \mathrm{~min}$ after forskolin washout), and $60 \mathrm{~min}$ after washout of forskolin in the presence of histamine. Force was normalized to that previously elicited by $109 \mathrm{mM}$ extracellular $\mathrm{K}^{+}$. Data are means \pm SEM with $n=6-9$. Symbols without error bars reflect data where the SEM was smaller than the symbol size. PLM phosphorylation was measured with a phosphospecific antibody and is normalized to the phosphorylation observed with histamine stimulation alone. MRLC and HSP20 phosphorylation was measured by isoelectric focusing and is reported as mol phosphorylation per mol protein. The dashed lines are the values with $10 \mu \mathrm{M}$ histamine alone.

forskolin to the histamine-stimulated tissue from 30 to 45 min increased $\operatorname{ser}^{16}$-HSP20 phosphorylation and decreased $\operatorname{ser}^{19}$-MRLC phosphorylation in parallel with the relaxation. In contrast, ser $^{68}$-PLM phosphorylation only significantly increased after $15 \mathrm{~min}$ of forskolin treatment, indicating a slower change in $\operatorname{ser}^{68}$-PLM phosphorylation than a change in force. Washout of

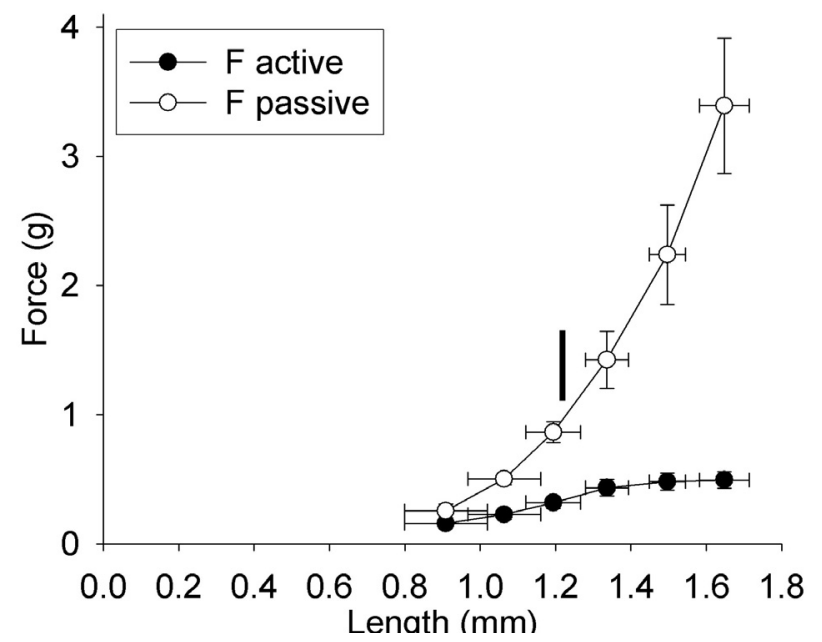

Fig. 2. The length tension relationship of $\mathrm{PLM}^{+/+}$mouse abdominal aortae. Eight $\mathrm{PLM}^{+/+}$abdominal aortae from 5-monthold mice were mounted on wire myographs. Aortae were repeatedly contracted with $109 \mathrm{mM}$ extracellular $\mathrm{K}^{+}$at varying tissue lengths. Passive force (open circles) was the minimal force measured when tissues were released to a given length from a longer length when bathed in PSS $\left(\mathrm{K}^{+} 4.7 \mathrm{mM}\right)$. Active force (filled circles) was the peak force measured upon activation with $109 \mathrm{mM} \mathrm{K}^{+}$at each length. Data are presented as mean \pm SEM. Symbols obscure some of the smaller error bars. The vertical bar indicates the length at 1 gram-weight.

forskolin in the continued presence of histamine reduced $\mathrm{ser}^{16}$-HSP20 phosphorylation and increased $\operatorname{ser}^{19}{ }^{19}$ MRLC phosphorylation in parallel with the recontraction. $\mathrm{Ser}^{68}$ PLM phosphorylation remained elevated during the recontraction. During forskolin-induced relaxation and recontraction, ser1 $1^{57}$-HSP20 phosphorylation remained high and did not significantly change.

Prior to evaluation of $\mathrm{PLM}^{-/-}$abdominal aortae, we evaluated how to set tissue length (diameter) in mouse infrarenal aorta. Fig. 2 shows the $109 \mathrm{mM} \mathrm{K}^{+}$-induced length-tension relation of wild type $\left(\mathrm{PLM}^{+/+}\right)$aortae. Despite increasing passive force to values $\sim 700 \%$ higher than active force, no descending limb of the lengthtension relation was observed. This response differs significantly from that observed in the swine carotid, where there is a descending limb of the length-tension relation and maximal active force is observed when passive force is $\sim 10 \%$ of active force (Herlihy and Murphy 1973). Since the length-tension relation did not define an optimal length for force development, we chose to set a length based on a physiologic arterial pressure of $100 \mathrm{mmHg}$ and the Laplace equation for wall stress. Laplace states that wall stress $=$ pressure $\mathrm{x}$ vessel internal radius $=100 \mathrm{~mm} \mathrm{Hg} \times 0.4 \mathrm{~mm}=1.33 \times 10^{4} \mathrm{~N} \mathrm{~m}^{-2} \times 4 \times$ $10^{-4} \mathrm{~m}=5.33 \mathrm{~N} \mathrm{~m}^{-1}$. Therefore, for a $2 \mathrm{~mm}$ long vessel, wall stress $=5.33 \mathrm{~N} \mathrm{~m}^{-1} \times 2 \times 10^{-3} \mathrm{~m}=1.1 \times 10^{-2} \mathrm{~N}=$ 

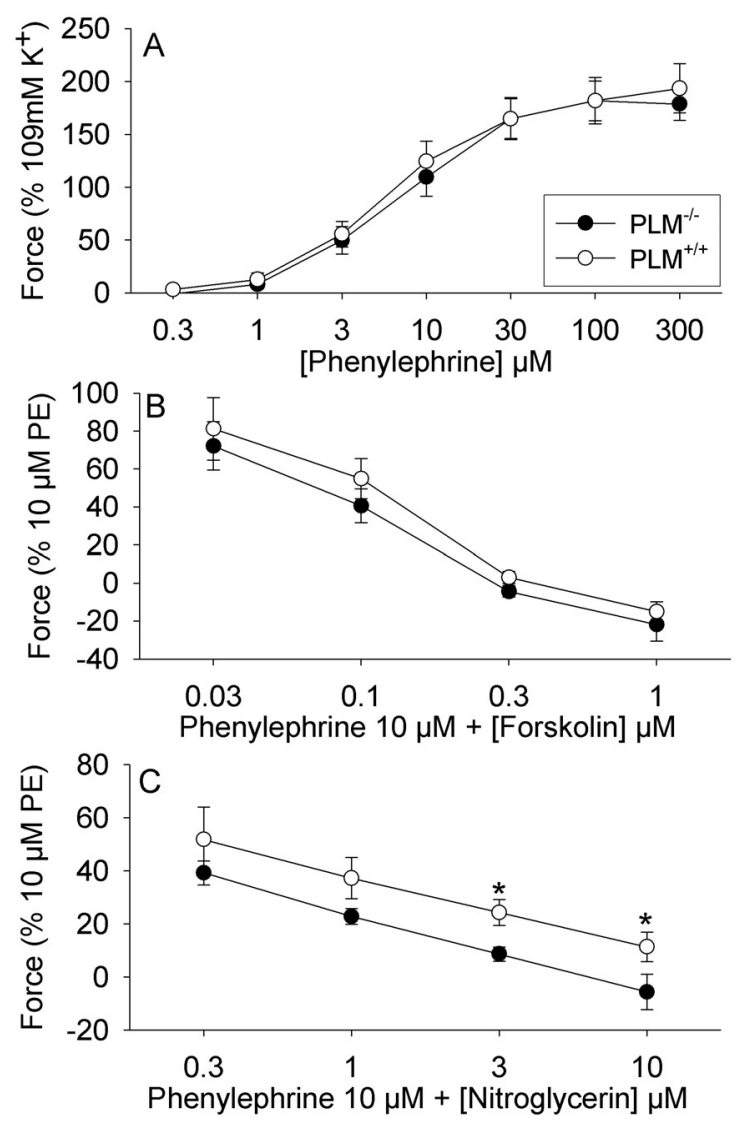

Fig. 3. Comparison of contractile and relaxant responses in PLM ${ }^{-}$ 1- and $\mathrm{PLM}^{+/+}$mouse aortae. Eleven $\mathrm{PLM}^{-1-}$ (open circles) and ten $\mathrm{PLM}^{+/+}$(filled circles) aortae from 5-month-old mice were mounted on wire myographs. After setting resting force to $\sim 1$ gram-weight, aortae were contracted with $109 \mathrm{mM}$ extracellular $\mathrm{K}^{+}$to determine the force for later normalization. After washout of high $\mathrm{K}^{+}$, aortae were contracted with cumulatively increasing concentrations of phenylephrine as shown in the panel $A$ (forces normalized to the prior $\mathrm{K}^{+}$contraction). After washout of phenylephrine, aortae were then contracted to an intermediate force with $10 \mu \mathrm{M}$ phenylephrine and relaxed with cumulatively increasing concentration of forskolin as shown in panel B (forces normalized to the $10 \mu \mathrm{M}$ phenylephrine contraction). After washout of phenylephrine and forskolin, aortae were contracted to an intermediate force with $10 \mu \mathrm{M}$ phenylephrine and relaxed with cumulatively increasing concentration of nitroglycerin as shown in panel $\mathrm{C}$ (forces normalized to the $10 \mu \mathrm{M}$ phenylephrine contraction). In approximately half of the arteries, the order of forskolin- and nitroglycerin-induced relaxation was switched. Data are presented as mean \pm SEM with * indicating a significant difference between the $\mathrm{PLM}^{-/-}$and $\mathrm{PLM}^{+/+}$aortae by unpaired $\mathrm{t}$ test. Symbols obscure some of the smaller error bars.

1.1 gram-weight. We therefore set passive force to be $\sim 1$ gram-weight to attain a resting wall stress approximating an arterial pressure of $100 \mathrm{~mm} \mathrm{Hg}$.

We then studied contractile and relaxant behavior in $\mathrm{PLM}^{-/-}$and $\mathrm{PLM}^{+/+}$mouse infrarenal aortae. There was no difference in the phenylephrine contractile dose response observed in the $\mathrm{PLM}^{-/-}$and $\mathrm{PLM}^{+/+}$aortae
(Fig. 3A). In aortae precontracted with $10 \mu \mathrm{M}$ phenylephrine, forskolin induced a relaxation, and there was no difference in the forskolin dose response observed in the $\mathrm{PLM}^{-/}$and $\mathrm{PLM}^{+/+}$aortae (Fig. 3B). In aortae precontracted with $10 \mu \mathrm{M}$ phenylephrine, nitroglycerin induced a slightly greater relaxation in $\mathrm{PLM}^{-/}$aorta compared to $\mathrm{PLM}^{+/+}$aortae $(\mathrm{P}<0.05$, Fig. $3 \mathrm{C})$.

In a separate experiment, two $\mathrm{mm}$ long segments of abdominal aorta from four $\mathrm{PLM}^{-/-}$and four $\mathrm{PLM}^{+/+}$ mice were incubated freely floating in $10 \mu \mathrm{M}$ phenylephrine for $2 \mathrm{~min}$ followed by addition of $1 \mu \mathrm{M}$ forskolin for $30 \mathrm{~min}$. Tissues were then frozen for measurement of [cAMP]. [cAMP] did not significantly differ in $\mathrm{PLM}^{-/-}$aortae $\left(147 \pm 56 \mathrm{pmol} \mathrm{m}^{-1}\right.$, mean $\left.\pm \mathrm{SEM}\right)$ when compared to $\mathrm{PLM}^{+/+}$aortae $\left(334 \pm 147 \mathrm{pmol} \mathrm{ml}^{-1}\right.$, $\mathrm{p}=0.15)$.

\section{Discussion}

\section{Phospholemman}

Phospholemman (PLM) a 72 amino acid sarcolemmal protein that is abundant in heart, skeletal, and smooth muscle (Palmer et al. 1991). PLM has a physical and functional association with membrane ion transporters such as the Na,K-ATPase (Crambert et al. 2002, Feschenko et al. 2003) and the Na-Ca exchanger (NCX1) (Zhang et al. 2003, Mirza et al. 2004). These findings suggest that PLM may have functional roles similar to other members of the FXYD family of proteins (Sweadner and Rael 2000). For example, the gamma subunit of Na,K-ATPase (FXYD2) shares significant homology with PLM (Sweadner and Rael 2000) that could explain the effect of PLM on Na,K-ATPase activity (Mercer et al. 1993). In vitro, protein kinase A (PKA) induces PLM phosphorylation at $\operatorname{ser}^{68}$ while protein kinase C (PKC) induces phosphorylation at both $\operatorname{ser}^{63}$ and $\operatorname{ser}^{68}$ (Walaas et al. 1994, Mounsey et al. 1999). As noted in our previous paper (Rembold et al. 2005) and in Figure 1 , histamine and forskolin additively increased $\operatorname{ser}^{68}$ PLM phosphorylation, likely from histamine-induced PKC activation and forskolin-induced PKA activation, respectively.

We found that the time course of $\operatorname{ser}^{68}$ PLM phosphorylation was too slow to correlate with either the forskolin-induced relaxation (30 to $45 \mathrm{~min}$ in Fig. 1) or the recontraction observed when forskolin was washed out (45 to $105 \mathrm{~min}$ in Fig. 1). We also found that genetic absence of PLM (the PLM $^{-/}$mouse) was not associated with an alteration in the dose response of forskolin- 
induced relaxation of abdominal aorta (Fig. 3B). We tested whether a difference in forskolin-induced increases in [cAMP] could explain the absence of a forskolin dose response (perhaps the $\mathrm{PLM}^{-/-}$aorta had a compensatory larger forskolin-induced increase in [cAMP] to compensate for the absence of PLM in the $\mathrm{PLM}^{-/}$aorta). However, we found that the forskolin-induced increase in [cAMP] in the $\mathrm{PLM}^{-/}$mouse did not significantly differ from the $\mathrm{PLM}^{+/+}$mouse ([cAMP] actually tended to be lower in the $\mathrm{PLM}^{-/ 2}$ mouse compared to the $\mathrm{PLM}^{+/+}$ mouse). These data suggest that PLM is not involved in cAMP-mediated arterial relaxation in the mouse aorta or swine carotid.

We cannot rule out the possibility that the genetic absence of PLM increased the importance of other cAMP-mediated relaxation mechanisms. Reported cAMP smooth muscle relaxant mechanisms include i) inhibition of $\mathrm{Ca}^{2+}$ mobilization from the sarcoplasmic reticulum (Lincoln et al. 1996), ii) hyperpolarization (Rembold and Chen 1998), iii) decreased $\mathrm{Ca}^{2+}$ influx through voltage-gated channels (Knot et al. 1996), iv) activation of plasma membrane $\mathrm{Ca}^{2+}$ pumps (Raeymaekers and Wuytack 1996), and force suppression associated with ser $^{16}$-HSP20 phosphorylation (Rembold et al. 2001). Alternatively, it is possible that our normalization of forces by $\mathrm{K}^{+}$-induced contraction was inappropriate. Ideally, we should normalize force by tissue cross-sectional area. However, these tissues are too small to accurately measure weight. Arguing against a normalization artifact was the lack of a difference in the phenylephrine dose response in the $\mathrm{PLM}^{-/}$compared to $\mathrm{PLM}^{+/+}$aortae (Fig. 3A). This lack of a difference in phenylephrine dose response suggests that contractile mechanisms were not altered by the genetic absence of PLM.
We did find that the genetic absence of PLM in the $\mathrm{PLM}^{-/}$mouse was associated with a modest accentuation in nitroglycerin-induced relaxation (Fig. 3C). This is surprising given our finding that nitroglycerin did not induce ser ${ }^{68}$ PLM phosphorylation in the swine carotid (Rembold et al. 2005). These results suggest that PLM, despite the absence of nitroglycerininduced $\operatorname{ser}^{68}$ phosphorylation, may be involved in cGMP-mediated relaxation by an unknown mechanism. Further research is required to determine the mechanism how PLM is involved in cGMP-mediated relaxation.

\section{HSP20 and MRLC phosphorylation}

We found that the time course of $\operatorname{ser}^{19}$-MRLC dephosphorylation and the time course of $\operatorname{ser}^{16}$-HSP20 phosphorylation paralleled forskolin-induced relaxation (Fig. 1). These data suggest that forskolin-induced relaxation could be caused by the reduction in $\operatorname{ser}^{19}$ MRLC phosphorylation and/or the increase in $\operatorname{ser}^{16}$ HSP20 phosphorylation. Ser ${ }^{157}$ HSP20 phosphorylation did not change during contraction, relaxation, or recontraction, suggesting that $\operatorname{ser}^{157}$-HSP20 phosphorylation does not have a role in forskolin-induced relaxation. Further research is ongoing in our laboratory to determine whether $\operatorname{ser}^{16}$-HSP20 phosphorylation is required for forskolin-induced relaxation.

\section{Conflict of Interest}

There is no conflict of interest.

\section{Acknowledgements}

The authors thank Dr. Randall Moorman for the gift of PLM antibodies. A grant from the NIH (HL071191 (C.R.)) supported this research.

\section{References}

BÁRÁNY M, BÁRÁNY K: Dissociation of relaxation and myosin light chain dephosphorylation in porcine uterine muscle. Arch Biochem Biophys 305: 202-204, 1993.

BEALL A, BAGWELL D, WOODRUM D, STOMING TA, KATO K, SUZUKI A, RASMUSSEN H, BROPHY CM: The small heat shock-related protein, HSP20, is phosphorylated on serine 16 during cyclic nucleotidedependent relaxation. J Biol Chem 274: 11344-11351, 1999.

BEALL AC, KATO K, GOLDENRING JR, RASMUSSEN H, BROPHY CM: Cyclic nucleotide-dependent vasorelaxation is associated with the phosphorylation of a small heat shock-related protein. $J$ Biol Chem 272: 11283-11287, 1997.

BOULANGER-SAUNIER C., STOCLET J-C: A $16 \mathrm{kDa}$ protein substrate for protein kinase $\mathrm{C}$ and its phosphorylation upon stimulation with vasopressin receptors in rat aortic myocytes. Biochem Biophys Res Commun 143: 517$521,1987$. 
BOULANGER-SAUNIER C, KATTENBURG DM, STOCLET J-C: Cyclic AMP-dependent phosphorylation of a $16 \mathrm{kDa}$ protein in a plasma membrane-enriched fraction of rat aortic myocytes. FEBS Lett 193: 283-288, 1985.

CRAMBERT G, FUZESI M, GARTY H, KARLISH S, GEERING K: Phospholemman (FXYD1) associates with Na,K-ATPase and regulates its transport properties. Proc Natl Acad Sci USA 99: 11476-11481, 2002.

ETTER EF, ETO M, WARDLE RL, BRAUTIGAN DL, MURPHY RA: Activation of myosin light chain phosphatase in intact arterial smooth Muscle during nitric oxide-induced relaxation. J Biol Chem 276: 34681-34685, 2001.

FAN GC, CHU GX, KRANIAS EG: Hsp20 and its cardioprotection. Trends Cardiovasc Med 15: 138-141, 2005.

FESCHENKO MS, DONNET C, WETZEL RK, ASINOVSKI NK, JONES LR, SWEADNER KJ: Phospholemman, as single-span membrane protein, is an accessory protein of the $\mathrm{Na}, \mathrm{K}-\mathrm{ATPase}$ in cerebellum and choroid plexus. J Neurosci 23: 2161-2169, 2003.

GERTHOFFER WT, MURPHY RA: $\mathrm{Ca}^{2+}$, myosin phosphorylation, and relaxation of arterial smooth muscle. $A m \mathrm{~J}$ Physiol 245: C271-C277, 1983.

HERLIHY JT, MURPHY RA: Length-tension relationship of smooth muscle of the hog carotid artery. Circ Res 33: 275-283, 1973.

JERIUS JH, KAROLYI DR, MONDY JS, BEALL AC, WOOTTON D, KU D, CABLE S, BROPHY CM: Endothelialdependent vasodilation is associated with increases in the phosphorylation of a small heat shock protein (HSP20). J Vasc Surg 29: 678-684, 1999.

JIA LG, DONNET C, BOGAEV RC, BLATT RJ, MCKINNEY JS, DAY KH, BERR S, JONES LR, MOORMAN JR, SWEADNER KJ, TUCKER AL: Hypertrophy, increase ejection fraction, and reduced Na,K-ATPase activity in phospholemman-deficient mice. Am J Physiol 288: H1982-H1988, 2005.

KNOT HJ, BRAYDEN JE, NELSON MT: Calcium channels and potassium channels. In: Biochemistry of Smooth Muscle Contraction, BÁRÁNY M (ed), Academic Press, San Diego, 1996, pp 203-219.

LINCOLN TM, CORNWELL TL, KOMALAVILAS P, MACMILLAN-CROW LA, BOERTH NJ: The nitric oxidecyclic gmp signaling system. In Biochemistry of Smooth Muscle Contraction, BÁRÁNY M (ed), Academic Press, San Diego, 1996, pp 257-268.

MCDANIEL NL, CHEN X-L, SINGER HA, MURPHY RA, REMBOLD CM: Nitrovasodilators relax arterial smooth muscle by decreasing $\left[\mathrm{Ca}^{2+}\right] \mathrm{i},\left[\mathrm{Ca}^{2+}\right] \mathrm{i}$ sensitivity, and uncoupling stress from myosin phosphorylation. Am $\mathrm{J}$ Physiol 263: C461-C467, 1992.

MCDANIEL NL, REMBOLD CM, RICHARD HL, MURPHY RA: cAMP relaxes arterial smooth muscle predominantly by decreasing cell $\left[\mathrm{Ca}^{2+}\right]$. J Physiol Lond 439: 147-160, 1991.

MEEKS M, RIPLEY ML, JIN Z, REMBOLD CM: Heat shock protein 20-mediated force suppression in forskolinrelaxed swine carotid artery. Am J Physiol 288: C633-C639, 2005.

MERCER RW, BIEMESDERFER D, BLISS DP jr, COLLINS JH, FORBUSH B III: Molecular cloning and immunological characterization of the gamma polypeptide, a small protein associated with the Na,K-ATPase. J Cell Biol 121: 579-586, 1993.

MIRZA MA, ZHANG X-Q, AHLERS BA, QURESHI A, CARL LL, SONG J, TUCKER AL, MOUNSEY JP, MOORMAN JR, ROTHBLUM LI, ZHANG TS, CHEUNG JY: Effects of phospholemman downregulation on contractility and $\left[\mathrm{Ca}^{2+}\right]$ (i) transients in adult rat cardiac myocytes. Am J Physiol 286: H1322-H1330, 2004.

MOUNSEY JP, LU KP, PATEL MK, CHEN ZH, HORNE LT, JOHN JE, III, MEANS AR, JONES LR, MOORMAN JR: Modulation of Xenopus oocyte-expressed phospholemman-induced ion currents by co-expression of protein kinases. Biochim Biophys Acta 1451: 305-318, 1999.

MURPHY RA, REMBOLD CM: The latch-bridge hypothesis of smooth muscle contraction. Can J Physiol Pharmacol 83: 857-864, 2005.

PALMER CJ, SCOTT BT, JONES LR: Purification and complete sequence determination of the major plasma membrane substrate for cAMP-dependent protein kinase and protein kinase C in myocardium. Journal of Biological Chemistry 266: 11126-11130, 1991.

RAEYMAEKERS L, WUYTACK F: Calcium pumps. In: Biochemistry of Smooth Muscle Contraction, BÁRÁNY M (ed), Academic Press, San Diego, 1996, pp 241-253.

REMBOLD CM: Relaxation, $\left[\mathrm{Ca}^{2+}\right] \mathrm{i}$, and the latch-bridge hypothesis in swine arterial smooth muscle. Am $J$ Physiol 261: C41-C50, 1991. 
REMBOLD CM, CHEN XL: Mechanisms responsible for forskolin-induced relaxation of rat tail artery. Hypertension 31: 872-877, 1998.

REMBOLD CM, FOSTER B, STRAUSS JD, WINGARD CJ, VAN EYK JE: cGMP mediated phosphorylation of heat shock protein 20 may cause smooth muscle relaxation without myosin light chain dephosphorylation. $J$ Physiol Lond 524: 865-878, 2000.

REMBOLD CM, O'CONNOR MJ, CLARKSON M, WARDLE RL, MURPHY RA: HSP20 phosphorylation in nitroglycerin- and forskolin-induced sustained reductions in swine carotid media tone. J Appl Physiol 91: 1460-1466, 2001.

REMBOLD CM, RIPLEY ML, MEEKS MK, GEDDIS LM, KUTCHAI HC, MARASSI FM, CHEUNG JY, MOORMAN JR: Serine 68 phospholemman phosphorylation during forskolin-induced swine carotid artery relaxation. $J$ Vasc Res 42: 483-491, 2005.

SARCEVIC B, BROOKES V, MARTIN TJ, KEMP BE, ROBINSON PJ: Atrial natriuretic peptide-dependent phosphorylation of smooth muscle cell particulate fraction proteins is mediated by cGMP-dependent protein kinase. J Biol Chem 264: 20648-20654, 1989.

SOMLYO AP, SOMLYO AV: Signal transduction by G-proteins, Rho-kinase and protein phosphatase to smooth muscle and non-muscle myosin II. $J$ Physiol Lond 522: 177-185, 2000.

SWEADNER KJ, RAEL E: The FXYD gene family of small ion transport regulators or channels: cDNA sequence, protein signature sequence, and expression. Genomics 68: 41-56, 2000.

WALAAS SI, CZERNIK AJ, OLSTAD OK, SLETTEN K, WALAAS O: Protein kinase C and cyclic AMP-dependent protein kinase phosphorylate phospholemman, an insulin and adrenaline-regulated membrane phosphoprotein, at specific sites in the carboxy terminal domain. Biochem J 304: 635-640, 1994.

WOODRUM DA, BROPHY CM, WINGARD CJ, BEALL A, RASMUSSEN H: Phosphorylation events associated with cyclic nucleotide-dependent inhibition of smooth muscle contraction. Am J Physiol 277: H931-H939, 1999.

ZHANG X-Q, QURESHI A, SONG J, CARL LL, TIAN R, STAHL RC, CAREY DJ, ROTHBLUM LI, CHEUNG JY: Phospholemman modulates $\mathrm{Na}^{+} / \mathrm{Ca}^{2+}$ exchange in adult rat myocytes. Am J Physiol 284: $\mathrm{H} 225-\mathrm{H} 233,2003$. 